\title{
Antibacterial and antioxidant activities of ethanol extract of Artocarpus lacucha Buch- Ham. leaves against Propionibacterium acne
}

\author{
Panal Sitorus ${ }^{1}$, Mahatir Muhammad ${ }^{1 *}$, Henni Cintya ${ }^{2}$, and Denni Satria ${ }^{2}$ \\ ${ }^{1}$ Department of Pharmaceutical Biology, Faculty of Pharmacy, Universitas Sumatera Utara, Jl. Tri \\ Dharma No.5, Kampus USU, Medan, 20155, Sumatera Utara, Indonesia. \\ ${ }^{2}$ Department of Pharmaceutical Chemistry, Faculty of Pharmacy, Universitas Sumatera Utara, Jl. Tri \\ Dharma No.5, Kampus USU, Medan, 20155, Sumatera Utara, Indonesia.
}

\begin{abstract}
Antioxidants can neutralize free radicals that can affect biological systems in the body that can cause degenerative diseases. Antibacterial active molecules have been identified from plants, and these chemicals are being utilized to develop new and promising treatments. The Mobe plant (Artocarpus lacucha Buch-Ham.) is a species of Artocarpus member of the Moraceae family. Includes a high proportion of phenolic compounds (flavonoids and phenolic acid). This research obtained to know about the biological activity of Artocarpus lacucha Buch-Ham and their total flavonoid and total phenolic content. The extract was prepared using the soxhletation technique using ethanol as the solvent. Antibacterial activity was determined using minimum inhibitor concentration. Propionibacterium acne can be inhibited at concentrations ranging from $300 \mathrm{ppm}$ to $25 \mathrm{ppm}$. The DPPH technique was used to assess antioxidant activity. The samples' total flavonoid and phenolic content were measured colorimetrically. The DPPH test revealed an antioxidant activity of 23.33 $\mathrm{g} / \mathrm{mL}$, which was used to compute the IC50. The extract's total phenolic (117.44 mg GAE/g) and flavonoid (3.54 mg QE/g) content were determined to be high.
\end{abstract}

\section{Introduction}

Free radicals are related to cancer, coronary artery disease, hypertension, diabetes, neurological issues, and aging [1,2]. As a consequence, an antioxidant that can provide free radicals with one or more electrons is required. Antioxidants are chemicals that protect the body's biological system from the harmful consequences of excessive oxidation [3]. They are substances that protect the body's biological system against the damaging consequences of processes or reactions that result in excessive oxidation.

Thus far, active antibacterial molecules have been identified from plants, and these molecules are being utilized to develop new and promising treatments. Plant-based antibiotics are safer than synthetic medications since they are sourced from plants rather

*Corresponding author: mahatir.muhammad@usu.ac.id 
than manufactured drugs. To supplement the previous, plants contain a large number of secondary metabolites such as tannins and lignin, as well as carotenes, flavonoids, and alkaloids, all of which occur in smaller amounts than primary metabolites such as carbohydrate and lipid, which occur in greater abundance in animal and plant tissues. Even though these chemicals are non-nutritive, antibacterial activities are believed to exist [4 - 6].

Natural materials are tested for their therapeutic potential using antioxidant, antibacterial, and other biological methods. A phenolic is an organic substance containing at least one aromatic ring filled with hydroxyl groups [7]. These chemicals have many biological properties, including antioxidant, antibacterial, and anticancer properties, and can be considered a phytomedicine index [8,9]. Plants' antibacterial properties are ascribed to alkaloids and organosulfur [10,11]. Their involvement in protein synthesis, enzyme activity, structural components, and allelopathy has also been demonstrated $[12,13]$.

Mobe plant (Artocarpus lacucha Buch-Ham.) is a Moraceae family. Includes a high concentration of phenolic compounds (flavonoids and phenolic acid, which have been proven to be effective as antitumor, antibacterial, antifungal, anticancer, and antiinflammatory medicines [14]. This research obtained to know about the biological activity of Artocarpus lacucha Buch-Ham and their total flavonoid and total phenolic content.

\section{Material and method}

\subsection{Material}

Artocarpus lacucha Buch-Ham leaves Artocarpus lacucha Buch Ham obtained from Toba Samosir, North Sumatra. Indonesia.

\subsection{Method}

\subsubsection{Extraction}

Artocarpus lacucha Buch-Ham The leaves were dried at $45^{\circ} \mathrm{C}$ before being pulverized. Simplicia (30 g) of Artocarpus lacucha Buch-Ham was weighed. A conical flask held 600 $\mathrm{mL}$ ethanol. The liquid is then filtered using Whatman paper and dried in a rotary evaporator and water bath [15].

\subsubsection{Antioxidant activity}

The antioxidant activity of DPPH was evaluated by its ability to scavenge free radicals. Absorbance was determined using a $516 \mathrm{~nm}$ wavelength. This research used quercetin as a comparison. IC50 is determined by calculating the absorbance to obtain the percentage of inhibition which is then made a calibration curve [16,17].

\subsubsection{Total phenolic}

Total phenol was determined by Folin ciocalteu reagent, a spectrophotometer measured the absorbance at $775 \mathrm{~nm}$ [18]. All tests were performed in triplicate to ensure their accuracy.

$$
C=\frac{c x V}{M} x F
$$


C: concentration derived from a standard curve $(\mu \mathrm{g} / \mathrm{mL}) ; \mathrm{V}$ : volume utilized in the assay (mL); M: sample mass (g); F: dilution factor.

\subsubsection{Total flavonoid}

A spectrophotometer set at a wavelength of $432 \mathrm{~nm}$ was used to measure the total flavonoid concentration. We built a calibration curve using quercetin as a reference to quantify the flavonoids in the sample. Quercetin equivalents ( $\mathrm{mg} / \mathrm{g}$ of extract) are used to quantify the extract's flavonoid concentration. [19] All tests were conducted in duplicate:

$$
C=\frac{c x V}{M} \times F
$$

$\mathrm{C}$ : Concentration of flavonoid as quercetin equivalent; V: volume used in the test $(\mathrm{mL}) ; \mathrm{M}$ : mass of the sample utilized in the assay $(\mathrm{g})$; and F: dilution factor

\subsubsection{Determination of minimum inhibitory concentration}

The extracts antibacterial activity was determined using the minimum inhibitory concentration (MIC) technique. Each treatment was administered six times in total. The minimal inhibitory concentration was determined using a microdilution technique in combination with Mueller Hinton Broth (MHB, Merck $\left.{ }^{\circledR}\right)$ as the test medium, with slight modifications. The bacteria used was Propionibacterium acne and the control used the antibiotic chloramphenicol [20,21].

$$
\text { Activity Index }=\frac{\text { inhibitor zone of sample }}{\text { inhibitor zone of positive-control (antibiotic) }} .
$$

\section{Results and discussion}

\subsection{Antioxidant activity, total phenol, and total flavonoid}

The ability of natural products to give electrons may be evaluated by bleaching them with the 1,1 -diphenyl-1-picrylhydrazyl radical (DPPH) solution [22], which results in a purplecolored solution. To scavenge DPPH, an antioxidant or radical species that decolorizes DPPH solution is employed with an antioxidant or radical species [23]. Table 1 summarizes the experiment's findings.

Table 1. Antioxidant activity

\begin{tabular}{|c|c|c|c|}
\hline Plant & Antioxidant & Total phenolic & Total flavonoid \\
\hline Artocarpus lacucha Buch-Ham. & $\begin{array}{c}23.33 \pm 0,13 \\
\mu \mathrm{g} / \mathrm{mL}\end{array}$ & $\begin{array}{c}117.44 \pm 0,17 \\
\mathrm{mg} \mathrm{GAE} / \mathrm{g}\end{array}$ & $\begin{array}{c}3.54 \pm 0,04 \mathrm{mg} \\
\mathrm{QE} / \mathrm{g}\end{array}$ \\
\hline
\end{tabular}

The ethanol extract of Artocarpus lacucha Buch-Ham showed very strong antioxidant activity in the $\mathrm{DPPH}$ technique. The $\mathrm{IC}_{50}$ value is defined as the sample concentration required to capture $50 \%$ of the DPPH radicals [24]. Due to their abundance and variety in plants, phenolic chemicals are categorized as secondary metabolites. These phytochemicals, derived from the amino acids phenylalanine and tyrosine, are present in many plants [25]. Phenolic compounds present in plants are particularly beneficial because their hydroxyl groups act as scavengers, making them an excellent source of antioxidants. It is widely 
established that diverse phenolic compounds respond differently when the Folin-Ciocalteu method is used. As with phenolic substances, these molecules' molecular antioxidant response varies considerably according to their structural makeup. Total flavonoids are very effective in scavenging the majority of oxidizing molecules, including singlet oxygen, as well as several free radicals implicated in a variety of diseases [26].

\subsection{Antibacterial activity}

When Propionibacterium acne is grown in a culture medium containing a concentration ranging from $300 \mathrm{ppm}$ to $25 \mathrm{ppm}$, the Minimum Inhibitory Concentration (MIC) is observed to be at the lowest concentration that is effective in inhibiting bacterial growth, and the number of bacteria in less than 10 colonies. The MIC of an antibiotic is determined by measuring the amount of bacterial colonies that grow after 24 hours of incubation [27]. Extract ethanol has the potential to inhibit the growth of Propionibacterium acne bacteria which can be seen from the Minimum Inhibitory Concentration as shown in Table. 2

Table 2. Result of antibacterial activity

\begin{tabular}{|c|c|c|c|c|c|c|}
\hline \multirow{2}{*}{ No } & \multirow{2}{*}{ Extract } & \multicolumn{4}{|c|}{ Inhibition zone diameter (Concentration $\mathrm{mg} / \mathrm{mL})$} \\
\cline { 3 - 7 } & 300 & 200 & 100 & 50 & 25 \\
\hline \multirow{3}{*}{1} & $\begin{array}{c}\text { Artocarpus lacucha } \text { Buch- } \\
\text { Ham. }\end{array}$ & $\begin{array}{c}10.90 \pm \\
0,10\end{array}$ & $\begin{array}{c}10.23 \pm \\
0,06\end{array}$ & $\begin{array}{c}10.03 \pm \\
0,06\end{array}$ & $\begin{array}{c}9.57 \pm \\
0,07\end{array}$ & $\begin{array}{c}8.37 \pm \\
0,05\end{array}$ \\
\hline
\end{tabular}

Antibacterial activity was shown by forming a clear zone around the disc in media grown with bacteria and supplemented with an extract at a specific concentration, confirming the compound's existence. The existence of a clean zone indicates that the Extract's antibacterial compounds can prevent microbial development and spread. Certain substances in the Artocarpus lacucha Buch-Ham. The Extract showed a high concentration of those compounds. The phytochemical composition of the extracts varied depending on the presence or absence of particular components. Glycosides, alkaloids, and flavonoids in Artocarpus lacucha Buch-Ham leaves. It was thought to be responsible for the plant's antibiotic capabilities, which have been tested against a variety of illnesses. This study's findings suggest that plant phytochemicals that slow or stop infection development should be investigated as possible antibacterial candidates [28].

\section{Conclusion}

The ethanolic extract of Artocarpus lacucha Buch-Ham contains a high level of antioxidant activity. It is capable of inhibiting the growth of Propionibacterium acne bacteria when tested using the MIC technique.

Thank you to the Research Center University of Sumatera Utara's "Hibah Talenta" Research Grant 2021.

\section{References}

1. J. Gruz, F. Ayaz, A.H. Torun, Food Chem., 124, (2011).

2. E. Santharam, P. Ganesh, R. Soranam, J. Chem. Pharm. Res., 7, (2015).

3. A. Almey, A.J. Khan, S. Zahir, M. Suleiman, R.K. Int Fd Res J. 17, (2010). 
4. S. Chanda, K. Rakholiya, R. Nair, Chinese Med., 2, (2011).

5. S.A.R. Naqvi, N. Mahmood, S. Naz, Med J Nutrition Metab., 6, (2013).

6. H. Ding, X. Yang, L. Xu, J Bioresour Bioproducts, 5, (2020).

7. C.D, Stalikas. J Separat Sci, 30, (2007).

8. A. Sahar, S.A.R, Naqvi, Z.A, Khan, J Chem Soc Pak., 35, (2013).

9. N. Asghar, S.A.R, Naqvi, Z. Hussain, Chem Cent J., 10, (2016).

10. G.R, Dwivedi, A. Maurya, D.K, Yadav, J Biomol Struct Dyn, 37, (2019).

11. K. Alhanout, S. Malesinki, N. Vidal, V. Peyrot, J.M. Rolain, J.M, Brunel, J Antimicrob Chemother, 65, (2010).

12. A. Sofrata, E.M. Santangelo, M. Azeem, A.K. Borg-Karlson, A. Gustafsson, K. Pütsep, PloS One, 6, (2011).

13. Y.K, Al-Majedy, A.A.H, Kadhum, A.A. Al-Amiery, A.B. Mohamad, Syst Rev Phar., 8, (2017).

14. M.F, Hossain, Int Res J Bio Sc., 5, (2016).

15. O.R. Alara. N.H. Abdurahman, C.I. Ukaegbu, N.H. Azhari N H. Industrial Crops and Products, 122, (2018).

16. D. Satria, J. Silalahi, G. Haro, S. Ilyas, P.A.Z. Hasibuan, Asian Pac J Cancer Prev., 18, (2017).

17. Nazliniwaty, A.H. Olivia, P. Dewi, S. Denny, M. Mahatir. The International Conference on Chemical Science and Technology, 2342, 080010 (2021).

18. M. Rosidah, M.F. Yam, A. Sadikun, M.Z. Asmawi, Pharm Bio, 46, (2008).

19. S. Jamuna, S. Pulsamy, K. Karthika, J App Pharm Sci., 2, (2012).

20. J. Boateng, and K.N. Diunase, Molecules. 20, (2015).

21. H. Urip, D. Aminah, H. Triana, M. Mahatir, Nasri, S. Denny. The International Conference on Chemical Science and Technology, 2342, 080011 (2021).

22. P.X. Nunes, S.F. Silva, R.J. Guedes, S. Almeida. Biological oxidations and antioxidant activity of natural products, Phytochemicals as nutraceuticals - Global Approaches to Their Role, in Nutrition and Health (2012).

23. D. Krishnaiah, R. Sarbatly, R.R. Nithyanandam, Food Bioprod Process, 89, (2011).

24. Naczk M, Shahidi F, 2004 J Chromatogr A., 47, (2004).

25. C. Ao, A. Li, A.A. Elzaawely, D.T. Xuan, S. Twata, Food Contrl, 19, (2008).

26. S. Sahreen, M.R. Khan, R.A. Khan, J Med Plants Res., 5, (2011).

27. G.J. Tortora, B.R. Funke, C.L. Case, Microbiology (Addison Wesley Longman Inc, USA, 2010).

28. R. Ashok kumar, and M. Ramaswamy, Int J Curr Microbiol Appl Sci, 3, (2014). 